\title{
Banka Hizmet Kalitesinin Kurumsal İmaj, Müşteri Tatmini ve Tekrar Satın Alma Davranışı Üzerindeki Etkisinin Yapısal Eşitlik Modeli ile Analizi (Analysis of the Effect of Bank Service Quality on Corporate Image, Customer Satisfaction and Repurchase Behavior with Structural Equation Model)
}

\section{Faruk DAYI iD a Bülent YILDIZ iD b}

a Kastamonu Üniversitesi, İktisadi ve İdari Bilimler Fakültesi, İşletme Bölümü, Kastamonu, Türkiye. fdayi@kastamonu.edu.tr b Kastamonu Üniversitesi, İktisadi ve İdari Bilimler Fakültesi, İşletme Bölümü, Kastamonu, Türkiye. byildiz@kastamonu.edu.tr

\begin{tabular}{|c|c|}
\hline MAKALE BİLGİsí & ÖZET \\
\hline Anahtar Kelimeler: & Amaç - Bireylerin ve işletmelerin fon ihtiyaçlarının karşılanmasında bankalar önemli bir rol \\
\hline Banka, Hizmet Kalitesi & oynamaktadır. Bankaların sundukları hizmetin kalitesi finansal performanslarını olumlu yönde \\
\hline Müşteri Memnuniyeti & rek, aktif kalitesini ve kârlarını artırmaktadır. Bankaların büyümeleri müş̧terilerin güven ve \\
\hline Yapısal Eşitlik Modeli & satın alınmasını doğrudan etkilediği gibi sunulan hizmetin kalitesiyle de yakından ilişkilidir. \\
\hline Aktif Kalitesi & $\begin{array}{l}\text { Hizmet kalitesinin artırılması müşteri memnuniyetini doğrudan etkilediğinden bu kavramlar } \\
\text { arasındaki ilişkinin incelenmesi amaçlanmaktadır. }\end{array}$ \\
\hline $\begin{array}{l}\text { Gönderilme Tarihi } 21 \text { Ekim } \\
2019\end{array}$ & $\begin{array}{l}\text { Yöntem - Veriler Kastamonu ilinde ikamet etmekte olan } 867 \text { banka müşterisinden anket yöntemi ile } \\
\text { toplanmıştır. Anketten elde edilen veriler SPSS } 22 \text { paket programında ölçek geçerlik ve güvenirlik, }\end{array}$ \\
\hline Revizyon Tarihi 9 Ocak 2020 & modeli ile test edilmiştir. \\
\hline Kabul Tarihi 7 Şubat 2020 & $\begin{array}{l}\text { Bulgular - Analiz sonucunda hizmet kalitesinin müşteri tatmini ve kurumsal imajı pozitif yönde } \\
\text { anlamlı olarak etkilediği tespit edilmiştir. Ayrıca müşteri tatmininin kurumsal imajı ve tekrar satın } \\
\text { alma niyetini pozitif yönde etkilediği bulgusuna ulaşılmışırı. }\end{array}$ \\
\hline $\begin{array}{l}\text { Makale Kategorisi: } \\
\text { Araştırma Makalesi }\end{array}$ & $\begin{array}{l}\text { Tartışma - Araştırma sonucunda bankacılık hizmet kalitesinin, müşteri tatmininin ve tekrar satın } \\
\text { alma niyetinin kamu ve özel bankalar arasında özel bankalar lehine anlamlı farklılık gösterdiği } \\
\text { bulgusu elde edilmiştir. }\end{array}$ \\
\hline
\end{tabular}

\begin{tabular}{|c|c|}
\hline ARTICLE INFO & ABSTRACT \\
\hline $\begin{array}{l}\text { Keywords: } \\
\text { Bank, Service Quality } \\
\text { Customer Satisfaction } \\
\text { Structural Equation Model } \\
\text { Asset Quality }\end{array}$ & $\begin{array}{l}\text { Purpose - Banks play an important role in meeting and financing the consumption needs of } \\
\text { individuals and Businesses. The quality of the service offered by banks in favor of their financial } \\
\text { performance positively increases the asset quality and profit. The growth of banks is closely related } \\
\text { to customers' sense of trust and belonging. Corporate image and customer satisfaction directly affect } \\
\text { the repurchase of the service and are also closely related to the quality of the service provided. Since } \\
\text { increasing service quality directly affects customer satisfaction, it is aimed to examine the } \\
\text { relationship between these concepts. }\end{array}$ \\
\hline $\begin{array}{l}\text { Received } 21 \text { October } 2019 \\
\text { Revised } 9 \text { January } 2020 \\
\text { Accepted } 7 \text { February } 2020\end{array}$ & $\begin{array}{l}\text { Design/methodology/approach - Data were collected from } 867 \text { bank customers residing in } \\
\text { Kastamonu. The data obtained from the questionnaire were analyzed in SPSS } 22 \text { statistic program } \\
\text { with statistical methods scale validity and reliability test, correlation test, confirmatory factor } \\
\text { analysis Furthermore, Hypothesis are tested with structural equation model. }\end{array}$ \\
\hline Article Classification: & $\begin{array}{l}\text { Findings - As a result of the analysis, it has been determined that service quality has a positive effect } \\
\text { on customer satisfaction and corporate image. In addition, it was found that customer satisfaction } \\
\text { positively affected the corporate image and intention to buy again. }\end{array}$ \\
\hline Research Article & $\begin{array}{l}\text { Discussion - As a result of the research, it was also found that the quality of banking service, } \\
\text { customer satisfaction and intention to buy again showed a significant difference between public and } \\
\text { private banks in favor of private banks. }\end{array}$ \\
\hline
\end{tabular}




\section{GIRISŞ}

Bankalar, diğer hizmet işletmelerinden farklı olarak, müşterilerine finansal hizmet sunmaktadır. Hizmet kalitesi, müşterinin banka memnuniyetini doğrudan etkileyen önemli bir unsurdur. Hizmet kalitesi, bankaların gelirlerini ve kârını etkilemektedir. Bankalar, müşterilerin beklentileri karşılayarak hem kârını hem de müşterinin bankaya olan sadâkatini artırmakta ve müşteride tekrar satın alma güdüsü uyandırmaktadır. Ayrıca hizmetin güven ve güvenilirliği müşterilerin beklentisini ve hizmet algısını doğrudan etkilemektedir. Çünkü müşterinin beklentisini karşılayan hizmet kalitesi, bankanın kurumsal imajına olan bağlılığını ve hizmeti yeniden satın alma eğilimini doğrudan etkilemektedir. Müşterilerin bekledikleri hizmetin kalitesi arttıkça, bankanın beklediği kâr da artmaktadır (Berry vd., 1994:32). Bankalar, müşterilerin beklentileri karşılayarak hem kârını hem de müşterinin bankaya olan sadâkatini artırmakta ve müşteride tekrar satın alma güdüsü uyandırmayı amaçlamaktadır. Müşterinin beklentisini karşılayan hizmet kalitesi, bankanın kurumsal imajına olan bağlılı̆̆ını ve hizmeti yeniden satın alma eğilimini etkilemesi beklenmektedir.

Bankalar, müşterilerin beklentileri karşılayarak müşterinin bankaya olan sadâkatini artırarak, müşterilerde tekrar satın alma güdüsü uyandırmayı amaçlar. Banka hizmet kalitesinin güvenilirliği müşterilerin beklentisini ve hizmet algısını etkileyebileceği düşünülmektedir. Müşterilerin bankanın kurumsal imajına olan bağlılığını ve hizmeti yeniden satın alma eğilimini hizmet kalitesi etkileyebilmektedir.

Yoğun bir rekabet görülen bankacılık sektöründe hizmetlerin fiyatlamasında farklılık olabilmektedir. Müşteriler, düşük faiz oranıyla kredi kullanmak isterken; mevduatlarına işleyen faizin yüksek oranda olmasını beklerler. Benzer bir durum katılım bankacılığı için de geçerli olup, müşteriler düşük maliyeti tercih ederken, bankalar ise yüksek oranda kâr payı ile finansman kullandırmak isterler (Doğan, 2013:176). Katılım bankalarının genellikle yüksek kâr payı almalarından dolayı faiz hassasiyeti olmayan müşterilerin katılım bankalarından hizmet almayı tercih etmedikleri bilinmektedir.

Müşterilerin bankalardan hizmet satın almalarında bankaya duydukları güven önemli bir etkendir. Türkiye'de görülen ekonomik ve finansal krizler birçok bankanın batmasına neden olmuş ve müşterilerin güvenini sarsmıştır (Demirel vd., 2013:103-104). Bu nedenle müşterilerin bankaya güven duyması, bankadan tekrar hizmet satın alma güdüsü uyandırabilmektedir. Müşteri sadakati ve yeniden satın alma duygusu bankanın hizmet kalitesiyle ilişkili olduğu gibi güven ve güvenirlik düzeyiyle de birlikte değerlendirilmektedir. Müşteri memnuniyetinin artmasıyla birlikte müşterilerde tekrar satın alma isteği uyandığından, banka müşterilerinin sayısı artarak bankalar daha fazla gelir elde edebilir. Gelirlerin artmasıyla, kâr ve kârlılığın da artması beklenmektedir. Dolayısıyla sunulan hizmet kalitesi bankanın finansal performansını doğrudan etkilemektedir (Altan ve Atan, 2004:17).

Toplanan mevduat, kullandırılan kredi, bankaların likiditesi finansal varlıklarının büyüklüğüne bağlıdır. Bankaların finansal durumlarının değerlendirilmesinde toplam aktif tutarı ve Öz kaynaklar kullanılan önemli göstergelerdendir. Hizmet kalitesini artırmak ve daha uygun maliyetle hizmet sunmak isteyen bankaların finansal durumlarının güçlü olması beklenmektedir. Böylece müşterilerin beklentisi karşılanmakta, memnun kalan müşteri bankayı tavsiye etmekte ve banka daha fazla gelir elde etmektedir. Çünkü kurumsal imaj hizmet kalitesi beklentisini doğrudan etkilemektedir. Varlıkların kalitesi ve yüksek tutarlarda oluşu, işletmelerin faaliyet gösterdiği sektördeki rekabet düzeyini etkilediği ifade edilmektedir (Eroğluer, 2013:29).

Albayrak ve Erkut (2005) bankaların finansal performanslarının finansal göstergeler ile değerlendirilmesinin yeterli olmadığını, hizmet kalitesinin de dikkate alınması gerektiğini ifade etmişlerdir. Çalışmada bankacılık hizmet kalitesinin, kurumsal imaj ve müşteri tatmini ile yeniden satın alma arasındaki ilişki incelenmiştir. Uygulamanın Kastamonu'da yapılmış olması, Kastamonu'daki banka şubelerinin hizmet kalitesinin değerlendirilmesi açısından literatüre katkı sağlaması beklenmektedir.

\section{LITERATÜR}

\subsection{Bankaların Finansal Performansının Değerlendirilmesinde Aktif Kalitesi}

Bireyler ve işletmeler, ihtiyaç duydukları fonları temin etmek için bankaya başvurmaktadır. Ekonomik ve finansal sistemin önemli bir parçası olan bankacılık sisteminin güçlü ve sağlam bir alt yapıya sahip olması müşterilere güven vermektedir. Krizlerin en çok görüldüğü ekonomilerden biride Türkiye'dir. Krizler genel olarak iktisadi ve finansal olarak ikiye ayrılmakta, bankacılık sektöründe görülen krizler finansal krizler 


\section{F. Day1 - B. Yıldız 12/1 (2020) 1-17}

kategorisinde sinıflandırılmaktadır (Afşar, 2011:146-147). 1990'1 yıllarda, Kasım 2000 ve Şubat 2001 tarihlerinde Türkiye'de yaşanan ekonomik ve finansal krizler, bankacılık sektörünün finansal yapısının sağlam olmasının önemini ortaya çıkarmıştır. Çünkü para ve finansal piyasalar, bankaların finansal performanslarından doğrudan etkilenmektedir. 2008 yılında yaşanan küresel finansal kriz ile finans piyasalarındaki yatırım araçlarının getirileri de olumsuz yönde etkilenmiştir (Konak ve Kendirli, 2014:283284).

Finansal kriz müşterilerin bankadan bekledikleri hizmet kalitesini doğrudan etkilemektedir. Bankacıllk sistemininde görülen herhangi bir problem ekonomiyi olumsuz yönde etkileyebilmektedir. Türkiye'de yaşanan finansal krizler bankacılık sektörünün çökmesine neden olmuş, binlerce müşteri ve işletme olumsuz yönde etkilenmiştir. Türkiye'de yaşanan Şubat 2001 krizi, kur, faiz ve aktif kalitesindeki yetersizlikten kaynaklanmıştır (Çolak, 2012:1). Özkaynakların yetersizliği, aktif kalitesinin düşüklüğü, kontrol ve denetim mekanizmasının etkin olmayışı gibi faktörler bankacılık sisteminin krizlerden olumsuz yönde etkilenmesine neden olmuştur (Taşkın, 2011:290). 1997-2002 döneminde 18 banka çeşitli sebeplerden dolayı TSMF'ye (Tasarruf Mevduatı Sigorta Fonu) devredilmşitir (Çelik, 2010:133). Bankaların aktifleri ile özkaynaklarının yetersizliği, finansal yapılarının bozulmasına neden olabilmektedir. Bu nedenle bankaların varlıklarının değerlendirilmesi için aktif kalitesinin incelenmesi gerekmektedir (Emir ve Atukalp, 2018:588).

Finansal performans, hizmet kalitesinden doğrudan etkilenmektedir. Bankaların finansal performanslarının değerlemesinde aktif kalitesini ölçmek için aktif kârlılık oranı kullanılmaktadır (Gülhan ve Uzunlar, 2011:343). Bankaların müşterilerine güven verebilmesi için aktifleri ile özkaynaklarını yüksek tutarlarda bulundurması beklenmektedir. Aktif kalitesi yüksek olan bankalar daha fazla kâr elde ederek, özkaynaklarını güçlendirebilmektedir. Türkiye'de birey ve işletmelerin tasarrufları istenilen düzeyde olmadığından, aktif kalitesinin artması yabancı sermaye yatırımları ile mümkün olabilmektedir. Bankacılık sektöründe yapılan doğrudan yabancı sermayeli yatırımlar kamu bankalarının sektördeki ağırlı̆̆ını azaltmış ve özel bankaların aktif kalitesini artırarak sektördeki rekabeti yükseltmiştir (Sakarya, 2010:11). 2005 yılında bankacılık sektöründeki yabancıların payı \%5,2 iken 2006 yılında oran \%12'e yükselmiştir (Aktaş ve Kargın, 2007:36). Günümüzde ise bu oranın daha yüksek olduğu tahmin edilmektedir.

ABD'de banka denetçileri, bankaların aktif kalitesini değerlendirirken kredi verilmeden önce müşteriler için gerekli incelemelerin yapılıp yapılmadığının iyice araştırılması, kredi kullandırma sistemindeki etkinliğe dikkat edilmesi, sorunlu alacakların izlenmesi, tahsil süreci ve tahsil edilmesindeki başarı oranına bakılması, kullandırılan krediler için ayrılan karşılıklar ve takipteki alacaklar izlenmesi, bankalarda iç denetim sisteminin etkin çalışıp çalışmadığı ve bilginin doğru zamanda aktarılıp aktarılmadığına dikkat edilmesi gerektiği belirtilmiştir (Sakarya, 2010:14).

2018 yılı aktif büyüklüklerine göre ilk 10 da yer alan bankaların toplam aktifleri, toplam özkaynakları, net dönem kârları, şube sayıları ve çalışan sayıları Tablo 1'de verilmiştir.

Tablo 1. Aktif Büyüklüklerine Göre Bankaların Listesi

\begin{tabular}{c|l|c|c|c|c|c}
\hline Sıra & Bankalar & $\begin{array}{c}\text { Aktif } \\
\text { Toplamı } \\
\text { (Milyon) }\end{array}$ & $\begin{array}{c}\text { Özkaynaklar } \\
\text { Toplamı } \\
\text { (Milyon) }\end{array}$ & $\begin{array}{c}\text { Net } \\
\text { Dönem } \\
\text { Kârı } \\
\text { (Milyon) }\end{array}$ & $\begin{array}{c}\text { Şube } \\
\text { Sayısı } \\
\text { (Adet) }\end{array}$ & $\begin{array}{c}\text { Çalışan } \\
\text { Sayısı } \\
\text { (Adet) }\end{array}$ \\
\hline 1 & Türkiye Cumhuriyeti Ziraat Bankası A.Ş. & 579.377 & 55.748 & 1.102 & 1.766 & 24.650 \\
2 & Türkiye İş Bankası A.Ş. & 425.982 & 50.413 & 1.458 & 1.336 & 24.399 \\
3 & Türkiye Halk Bankası A.Ş. & 407.034 & 29.168 & 305 & 998 & 18.620 \\
4 & Türkiye Garanti Bankası A.Ş. & 384.384 & 48.192 & 1.722 & 930 & 18.295 \\
5 & Yapı ve Kredi Bankası A.Ş. & 368.999 & 39.070 & 1.241 & 854 & 17.379 \\
6 & Türkiye Vakıflar Bankası T.A.O. & 363.224 & 28.615 & 651 & 950 & 16.811 \\
7 & Akbank T.A.Ş. & 356.833 & 47.564 & 1.413 & 780 & 13.165 \\
8 & QNB Finansbank A.Ş. & 169.802 & 14.858 & 631 & 543 & 12.365 \\
9 & Denizbank A.Ş. & 146.907 & 15.944 & 492 & 710 & 12.094 \\
10 & Türk Ekonomi Bankası A.Ş. & 102.173 & 10.010 & 312 & 496 & 9.168 \\
\hline
\end{tabular}

Kaynak: (TBB, 2019) 


\section{F. Dayı - B. Yildız 12/1 (2020) 1-17}

Aktif toplamı en yüksek bankalar arasında Eximbank 9.sırada yer almakta olup perakende bankacilık hizmeti sunan geleneksel bankalardan olmadığı için tablodan çıkarılmıştır. Tablo 1'deki veriler incelendiğinde 580 milyar lira toplam aktif ve 56 milyar lira özkaynaklar ile Türkiye' de ki en güçlü banka T. C. Ziraat Bankası' dır. Türkiye İş Bankası 436 milyar lira toplam aktif ile ikinci sırada olup özkaynakları toplamı 50 milyar liradır. 407 milyar toplam aktif Türkiye Halk Bankası üçüncü sıradadır. Türkiye' de toplam aktif tutarı en düşük banka 57 milyon lira ile Adabank'tır. Net dönem kârları incelendiğinde 1,72 milyar lira ile en yüksek net dönem kârı Türkiye Garanti Bankası'nındır. Türkiye İş Bankası 1,45 milyar ile en yüksek net kâra sahip ikinci bankadır. 1,41 milyar net dönem kârı ile Akbank üçüncü sırada yer almaktadır. Aktif büyüklüğüne göre ilk üçte yer alan iki kamu bankasının ne dönem kârlarına göre ilk üçte yer almadıkları görülmektedir. Şube ve çalışan sayısına göre ilk üç sıradaki bankalar sırasıyla, T.C. Ziraat Bankası, Türkiye İş Bankası ve Türkiye Halk Bankası'dır.

Banka müşterileri aktif kalitesi yüksek olan bankaları güvenilir olarak değerlendirebilir. Aktif tutarının yüksek olması, bankanın kurumsal değerinin de yüksek olabileceğini düşündürmektedir. Bankaların sundukları hizmetin kalitesi arttıkça müşterilerin banka memnuniyetleri de artabilecektir. Aktif kalitesi bankaların finansal performanslarını değerlendirmekte önemli olduğu gibi finansal tablo kullanıcıları içinde önemli bir veri kaynağıdır. Bankaların hizmet kalitesinin artmasında aktif kalitesinin önemli bir payının olduğu düşünülmektedir. Bankaların aktif kalitesinin yüksek oluşu, müşterilerin bankaya olan güvenini olumlu yönde etkileyebilmektedir. Aktif kalitesi yüksek olan bankaların kurumsal imajlarının da yüksek olması beklenmektedir.

\subsection{Bankalarn Hizmet Kalitesi}

Bankaların finansal performanslarını değerlendirirken kullanılan göstergelerden biri de algılanan hizmet kalitesidir (Albayrak ve Erkut, 2005:53). Bankacilık sektöründe hizmet kalitesi, müşterinin beklentilerinin karşılanmasında bankanın gösterdiği performans düzeyi veya bankanın hizmetinden müşterinin algıladığ1 memnuniyet düzeyidir (Toktaş ve Gül, 2016:10). Hizmet kalitesi, müşterilerin beklentisi doğrultusunda hizmetin daha iyi nasıl gerçekleştirilebileceğini gösterecek bir göstergedir (Albayrak ve Erkut, 2005:48). Hizmet kalitesinin değerlendirilmesi, mal veya ürünün kalitesinin değerlendirilmesinden daha güçtür (Eroğluer, 2013:30). Hizmetin özelliklerinin farklı olması kalitesinin ölçülmesi ve değerlendirilmesini güç kılmaktadır (Usta ve Memiş, 2009:89).

Bankaların hizmet kalitesi, müşterilerinin beklentileri ile hizmetin sunulduğu kanala göre farklılık gösterebilmektedir. Bilişim ve telekomünikasyon teknolojisindeki gelişmelere paralel olarak bankacılık sektörünün sunduğu hizmetlerin çeşitliliği de artmıştır. 1990'lı yıllarda bankacılık hizmetleri sadece şubelerden yapılmaktaydı. Müşteriler şubeye giderek, şubenin yoğunluğuna göre sira bekleyerek temel bankacılık işlemlerini yaparlardı. Müşterilerin bankalardan aldığı hizmetin büyük bir kısmı, elektrik, su, telefon faturaları gibi bankacılıkla doğrudan ilgili olmayan işlemlerden oluşmaktaydı. 2000'li yılların başında bankacılık sektöründe internet bankacılığı önem kazanmış, müşterilerin adaptasyon süreci zaman almıştır. İlk yıllarda internet hizmeti pahalı olduğundan internete erişim sınırlıdı. İnternet hizmeti genellikle şehir merkezlerinde sunulmaktaydı. İnternet bankacılığı hizmetinden yararlanmak için hem bilgisayara hem de internet servis sağlayıcısından satın alınan internet hizmetine sahip olmak gerekmekteydi. Bu nedenle internet bankacılığı kullanan müşteri sayısı sınırlıydı. Bazı müşteriler ise internet bankacılığını güvenlik nedeniyle kullanmak istemiyordu. Bilişim ve yazılım teknolojisinin gelişmesiyle birlikte çeşitli algoritmalar geliştirilerek, bilgisayar yazılımlarının ve internet kullanımının güvenlik düzeyi yükselmiştir. Bankaların, internet bankacılığı hizmetinde sundukları siber güvenlik sertifikalarıla internet bankacilı̆̆na güven artmıştır.

Günümüzde internet kullanımının artmasıyla, müşterilerin internet bankacılığını daha fazla tercih ettikleri görülmektedir. İnternet üzerinden yapılan işlemler bankaların şubelerdeki iş yükünü de azaltmıştır. Böylece bankalar temel bankacilık hizmetlerinin kalitesini artırarak müşteriye daha kaliteli hizmet sunabilmektedir. Müşterinin bankaya gitmesine gerek kalmadan, gerçekleştirmek istediği işlemi internet üzerinden saniyeler içerisinde yaptığından, şubede saatlerde sıra beklemesine de gerek kalmamıştır. İnternet üzerinden yapılan işlemler bankaların şubelerindeki iş yükünü de azaltmış ve bankalar temel bankacılık hizmetlerine daha fazla önem vermeye başlamıştır. İnternet bankacılığı bankacılık sektörünün gelişmesinde önemli bir çı̆̆ır açmış, mobil bankacılık hizmetlerinin de alt yapısını oluşturmuştur. Müşteriler mobil iletişim araçlarıyla internet üzerinden kolayca mobil banka şubesine erişim sağlamakta ve dilediği işlemi hem çok hızlı hem de şubedeki 


\section{F. Dayı - B. Yildız 12/1 (2020) 1-17}

işlem ücretlerinden daha düşük fiyatlar ile yapabilmektedir. Mobil bankacılık hizmeti ile internet bankacilık hizmeti nitelik olarak aynı görülse de, internet bankacılığında sunulan hizmetler, mobil bankacılık şubesinden daha kapsamlıdır. Bankaların hizmet kalitesini artırma çabaları, satış ve dağıtım kanallarının çeşitlenmesinde etkili olmaktadır.

\subsection{Literatür Taraması}

Athanassopoulos (1997), banka şubelerinin etkinliği ile bankaların hizmet kalitesi arasındaki ilişkiyi incelemiştir. Uygulamada Yunanistan'daki büyük bir bankanın 68 şubesinin verileri kullanılarak Veri Zarflama Analizi yöntemi ile etkinlik analizi yapılmıştır. Bankaların şubelerindeki etkinlik düzeyi ile sunulan hizmetin kalitesi arasında pozitif yönlü bir ilişki olduğu vurgulanmıştır.

Bloomer vd. (1998), müşterilerin bankaya olan sadakatleri, bankadan aldıkları hizmetten duydukları memnuniyet ve bankanın sunduğu hizmetin kalitesini araştırmışlardır. Hollanda'da yaşayan 2.500 banka müşterisini telefon ile aranarak 17 sorudan oluşan anket yöntemi ile veri toplanmıştır. Korelasyon ve regresyon analizi sonucunda, müşterilerin memnuniyeti ile bankanın sunduğu hizmetin kalitesi ile sadakat arasında pozitif bir ilişki olduğu tespit edilmiştir.

Bahia ve Nantel (2000) algılanan hizmet kalitesinin bankalarda ölçülmesine yönelik geçerli ve güvenilir bir ölçek geliştirmek için yaptıkları çalışmada, bankaların 102 bireysel müşterisinden anket ile veri toplamıştır. Araştırmalarında müşterinin bankadan aldığı hizmetin kalite algısı ServQual tekniği ile incelenmiştir. ServQual kalite boyutları açısından yeni ölçeklerin geliştirilmesinin yararlı olacağını ifade etmişlerdir.

Gerrard ve Cunningham (2001) Singapur'daki bankaların hizmet kalitesini üç boyutta incelemiştir. Uygulama biri halka açık diğeri devlete ait olan iki bankanın müşterileri üzerinde yapılmıştır. Analiz sonuçları tüketicilerin mükemmel bir bankanın hizmet kalitesiyle ilgili beklentilerinin, halka açık ve devlet bankası arasında anlamlı derecede farklı olmadığını göstermiştir.

Aldlaigan ve Buttle (2002) bankaların hizmet kalitelerini değerlendirmek için yeni bir ölçek geliştirmişlerdir. Uygulamada 39 müşteriyle birebir görüşme yapılarak veri toplanmıştır. Elde ettikleri nitel veriler ile ölçek geliştirme çalışması yapmışlardır. Geliştirilen ölçeğin İngiltere'de ki bankaların hizmet kalitesinin ölçülmesinde kullanılabileceği tespit edilmiştir.

Patricio vd., (2003) internet bankacıllğ̆ ile entegreli, ATM, mobil bankacıllk ve şubeden yüz yüze sunulan hizmetlerin kalitesinin değerlendirilmesine yönelik Portekiz'deki bankalar üzerinde araştırma yapmışlardır. Uygulama da 36 müşteri ve 13 banka çalışanı ile görüşme yapılmıştır. Analiz sonuçlarına göre sunulan hizmetin kanalının etkinliğinin de performans üzerinde etkili olduğu bulgulanmıştır.

Altan ve Atan (2004) hizmet işletmelerinde kalite değerlendirmesinin, üretim işletmelerinden daha zor olduğunu, kalitenin öneminin her geçen gün arttığını ifade etmiştir. Bu nedenle hizmet kalitesinin ölçümüne yönelik ServQual tekniğini bankacıllk sektöründe değerlendirmişlerdir. Pamukbank ve Ziraat Bankası müşterileriyle yüz yüze görüşerek 60 anket yapılmıştır. ServQual skoru hesaplanarak $t$ testi ile bankaların hizmet kalitesi kalite boyutları açısından karşılaştırılmıştır. Pamukbank'ın hizmet kalitesi, Ziraat Bankasından daha yüksek çıkmıştır.

Erdoğan vd. (2006) Kütahya ilinde yaptıkları bir araştırmada şirketin imajını belirleyen faktörlerin; yenilikçilik, güvenilirlik, performans, sosyal sorumluluk, işveren imajı ve dağıtım kanalları şeklinde ortaya çıktığını tespit etmişlerdir.

Glaveli vd., (2006) Yunanistan, Bulgaristan, Makedonya, Arnavutluk ve Sirbistan'da faaliyet gösteren bankaların hizmet kaliteleri üzerinde müşteri algısını incelemişlerdir. Anketlerin dağılımı incelendiğinde Yunanistan'dan 153; Bulgaristan'dan 70; Arnavutluk'tan 40; Sırbistan'dan 40 ve Makedonya'dan 37 olmak üzere toplam 340 müşteriye anket yapılmıştır. Analizde $t$ testi ile faktör analizi yapılmış hizmet kalitesi 6 boyutuyla incelenmiştir. Bankaların hizmet kalitesi ve müşterilerin algısının ülkelere göre farklılık gösterdiği, bankalardan en çok memnun kalan müşterilerin Yunanistanlı oldukları ifade edilmiştir.

Demirel (2007) bankacılık sektöründe müşteri ilişkileri yönetiminin müşteri sadakati üzerine etkisini incelenmiştir. Uygulama kapsamında Türkiye'de faaliyet gösteren bankalardan A ve B bankaları seçilerek, bankaların 55 farklı şubesinde çalışan 395 personele anket yapılmıştır. Analizde korelasyon testi, faktör 


\section{F. Dayı - B. Yildız 12/1 (2020) 1-17}

analizi, ANOVA testi, regresyon analizi, varyans testi yapılmıştır. Müşteri ilişkileri yönetimin müşteri sadakati üzerine etkisi olduğu tespit edilmiştir.

Yılmaz vd., (2007) bankaların kalitesinin değerlendirilmesinin öneminin vurgulandığı çalışmada, müşterilerinin beklentileri ve algıladıkları hizmet kalitesini karşılaştırmışlardır. Müşterilerin bankalardan bekledikleri ve algıladıkları hizmet kalitesi ServQual ölçeği ile tespit edilmiştir. Uygulama için 250 kamu bankası ile 150 özel bankanın müşterilerinden anket ile veri toplamışlardır. Araştırma sonucuna göre özel ve kamu bankalarının hizmet kalitelerinin müşterileri memnun etmediği belirtilmiştir.

Ladhari vd., (2009) Tunus ve Kanada'daki bankaların hizmet kalitelerini müşteri memnuniyeti ve bağlllığ1 açısından karşılaştırmıştır. Çalışmada ServQual analizinin 5 boyutu ile değerlendirme yapılmıştır. Müşterilerden toplanan 477 anket verisi ile ANOVA testi yapılmıştır. Kanada ve Tunus'taki banka müşterilerinin banka kalite hizmet algılarında farklılıklar olduğu tespit edilmiştir.

Ustasüleyman (2009) banka müşterilerinin memnuniyetlerini etkileyen faktörlerin incelenmesinin bankacilık sektörünün gelişmesine önemli katkı sağlayacağını ifade etmektedir. Ticari bankaların hizmet kalitesini ve performansını belirlemek amacıyla yapılan araştırmada 3 ticari bankanın müşterilerinden toplanan 204 anketin verileri, kalitenin güvenirlilik, güven, empati ve fiziksel özellikler boyutları açısından Analitik Hiyerarşi Süreci ve TOPSIS yöntemleriyle incelenmiştir. Analiz sonuçlarına göre banka hizmet kalitesinde en önemli faktörün güvenilirlik $(0,451)$ olduğu tespit edilmiştir.

Çiçek ve Doğan (2009) ServQual ölçeği ile banka hizmet kalitesini değerlendirmişlerdir. Uygulama Niğde ilinde faaliyet gösteren kamu ve özel bankaların müşterilerine yapılmıştır. İkişer kamu ve özel banka müşterilerinden toplanan 320 anket ile analiz yapılmıştır. Müşterilerin bankadan bekledikleri kaliteden daha düşük kalitede hizmet aldıkları tespit edilmiştir. Bankadan beklenen en önemli kalite boyutunun güvence olduğu analiz sonuçlarında görülmektedir. Analiz sonuçları değerlendirildiğinde bankacilık sektöründeki hizmet kalitesi beklenti ve algısı arasındaki farkın diğer hizmet sektörlerindekinden daha fazla olduğu ifade edilmiştir.

Öncü vd., (2010) bankaların hizmet kalitesini önceki çalışmalardan farklı olarak ServPerf yöntemiyle incelemiştir. Zonguldak ilindeki 10 bankayı kapsayan araştırmada 204 banka müşterisine anket uygulanmış, faktör analizi, t testi ve ANOVA yöntemleriyle analiz yapılmıştır. Analiz sonuçlarına göre müşterilerin bankaları tercih etmelerinde, bankaların güvenilir olması ve bankanın müşteri ilişkilerine verdikleri önemin etkili olduğu tespit edilmiş̧ir. Bankaların hizmet kalitesinin değerlendirilmesinde en önemli boyutun fiziksel özellikler, en önemsiz boyutun ise empati olduğu tespit edilmiştir.

Taşkın vd., (2010) teknolojideki gelişmelerin müşterilerin ihtiyaç ve beklentilerini karşılaması gerektiğinden, bankaların sektörde rekabet edebilmesi için hizmet kalitesini geliştirmesi gerektiğini ifade etmişlerdir. Araştırma Bursa ilinde yapılmış olup 418 müşteriden anket yoluyla veri toplanmıştır. Frekans ve faktör analizi yapılmıştır. Analiz sonuçlarında müşterilerin banka tercihlerinde en önemli faktörün bankanın "güvenilir" olma özelliği olduğu tespit edilmiştir.

Bülbül vd., (2012) tarafından Türkiye'de faaliyet gösteren özel sermayeli bankaların sunduğu hizmet kalitesiyle ilgili müşterilerin beklentisi ve algısı araştırılmıştır. Müşteri tatmini, tekrar satın alma ve banka hizmet kalitesi arasındaki ilişki yapısal eşitlik modeli ile test edilmiştir. Uygulamada bir bankanın 500 müşterisinden anket yöntemiyle veri toplanmıştır. Analiz sonucunda müşteri hizmet kalitesi algısının beklentiyi karşılamadığı, sunulan hizmetin kalitesinin müşterinin tekrar satın alma davranışı üzerinde etkisi olmadığı ve müşteri tatmininin artmasıyla müşterinin tekrar satın alma davranışı gösterdiği ifade edilmiştir. $\mathrm{Bu}$ nedenle tekrar satın alma davranışı gösterilmesi için müşteri tatminini gerçekleşmesi gerektiği vurgulanmaktadır. Ayrıca çalışmalarında banka hizmet kalitesinin müşteri tatminini pozitif yönde anlamlı olarak etkilediğini bulgulamışlardır.

Shanka (2012), Etiyopya' daki özel bankalar tarafından sunulan hizmetin kalitesini incelemiştir. Araştırma için 220 müşteriden anket ile veri toplamıştır. Analiz sonuçlarına göre müşteri kalite beklentisi ile bankanın hizmet kalitesi boyutları arasında pozitif yönlü bir ilişki vardır. Bankanın müşteriye teklif ettiği diğer bir ifadeyle sunduğu hizmet kalitesi ile müşteri memnuniyetini olumlu yönde etkilediği ifade edilmiştir. 


\section{F. Dayı - B. Yildız 12/1 (2020) 1-17}

Yücel (2013) banka hizmet kalitesini ServQual tekniği ile incelemiştir. Malatya ilinde yapılan araştırmada 60 müşteriyle yüz yüze görüşülerek veri toplanmıştır. ServQual skoru hesaplanarak yapılan analizler sonucunda bankanın müşterilerin beklentilerini karşılayamadığı; bankanın sunduğu hizmette müşterilerin kalite algısının düşük olduğu tespit edilmiştir.

Şahin (2013) hizmet kalitesinin rekabet gücü ve pazar payı üzerinde etkili olduğunu; hizmet kalitesinin artmasıyla müşteri memnuniyeti ve sadakatinin arttığını ifade etmiştir. ServQual ölçeği kullanılarak bankacılık sektöründe hizmet kalitesinin cinsiyet açısından farklılık gösterip göstermediği incelenmiştir. Uygulamada banka müşterilerine 5'li Likert ölçeği ile 50 anket yapılmış, frekans, ağırlıklı ortalama ve $t$ testi ile analiz yapılmıştır. Araştırma sonucunda, görsel, güvenirlilik, güvence ve ilgi açısından beklentilerinin ve algı değerlerinin, erkeklerinkinden daha yüksek olduğu; duyarlılık boyutu açısından ise erkeklerin beklentilerinin kadınlardan daha yüksek olduğu tespit edilmiştir.

Eroğluer (2013) Balıkesir'de yaptığı bir araştırmada bankacılık hizmet kalitesi boyutlarından fiziksel özellikler ve güvenin kurumsal imajı pozitif yönde anlamlı olarak etkilediğini bulgulamıştır.

Işık vd., (2013) banka müşterilerinin bağlılıklarını etkileyen banka hizmet kalitesini ServPerf ölçeği ile incelemiştir. Araştırmada anket yöntemi kullanılmış ve 400 banka müşterisine anket uygulanmıştır. Elde edilen veriler faktör analizi, korelasyon, regresyon ve t testine tabi tutulmuştur. Katılımcıların en çok hizmet aldıkları beş bankanın üçü özel, ikisi kamu bankasıdır. Müşterilerin banka tercihinde maaş almak gibi zorunlu faktörlerin etkili olduğu ifade edilmiştir. Güvenilirlik, güvence ve cevap verilebilirlik açısından bankalar arasında herhangi bir anlamlı farklılık olmadığı belirtilmiştir. Kamu ve özel bankalar arasında dokunulabilirlik ve empati açısından istatistiksel olarak anlamlı bir farklılık olduğu tespit edilmiştir.

Arıvd., (2015) banka hizmet kalitesinin, müşterilerin sadakat ve bağlılıklarına etki eden faktörler yapısal eşitlik modeli ile incelenmiştir. Ankara' da yaşayan 229 banka müşterisine anket yapılmıştır. Analiz sonucunda müşterinin bankaya güveni, müşteriye sağlanan güvence, bankaya ve bankanın ATM hizmetine erişimin müşterilerin memnuniyetini ve sadakatini pozitif yönde etkilediği tespit edilmiştir.

Arı ve Yılmaz (2015) banka hizmet kalitesi ile banka sadakati arasındaki ilişkiyi incelemiştir. 285 İ̈̈BF öğrencisi ile yüz yüze görüşülerek anket yöntemi ile veri toplanmıştır. ServQual ölçeği kullanılarak doğrulayıcı faktör analizi yapılmış, yapısal eşitlik modeli önerilmiştir. Güvenirlik ve ATM hizmetinin bankalara duyulan memnuniyeti ve sadakati artırdığı sonucuna varılmıştır.

Kalyoncuoğlu ve Faiz (2016) müşterilerin bankadan aldıkları hizmetin kalitesinin bankanın imajı üzerinde etkisini incelemiştir. Düzce'de faaliyet gösteren kamu ve özel mevduat bankalarından hizmet alan 467 müşteriye anket yapılmıştır. Bankanın kendini müşterisiyle özdeşleştirmesinin kurumsal imaj üzerinde en etkili faktör olduğu tespit edilmiştir. Ayrıca araştırmalarında hizmet kalitesi boyutlarından fiziksel varlıklar, güvenilirlik, güvence ve özdeşleştirmenin kurumsal imajı anlamlı olarak etkilediğini tespit etmişlerdir.

Toktaş ve Gül (2016) bankanın hizmet kalitesini değerlendirmek için bir bankanın Ankara'da faaliyet gösteren şubesinin 392 müşterisinden anket ile veri toplamıştır. Araştırmalarını ServQual tekniği ile yapmışlardır. Araştırmaları sonucu bankanın hizmet kalitesinin müşterilerin beklentisini karşılamadığı tespit edilmiştir.

\section{ARAŞTIRMANIN MODELI VE YÖNTEMI}

$\mathrm{Bu}$ çalışmada bankacılık hizmet kalitesinin kurumsal imaj, müşteri tatmini ve tekrar satın alma niyeti üzerindeki etkisi araştırılmıştır. Ayrıca kurumsal imaj ve müşteri tatmininin tekrar satın alma niyeti üzerindeki etkisi incelenmiştir.

\subsection{Araştırmanın Modeli}

Bankaların hizmet kalitesinden memnun kalan müşteriler bankacılık hizmetini aynı bankadan yeniden satın alma davranışı gösterebilmektedir. Ayrıca bankanın hizmet kalitesi kurumsal imaj ile birlikte hizmetin tekrar satın alınmasında etkili olabilmektedir. Bankacılık hizmetinden memnun kalan müşterinin hizmeti tekrar satın alma eğilimi göstermesi de beklenmektedir. Bankacılık hizmet kalitesi, kurumsal imaj ve müşteri tatmini ile yeniden satın alma arasındaki ilişkiyi gösteren araştırmanın modeli Şekil 1'de verilmiştir. 


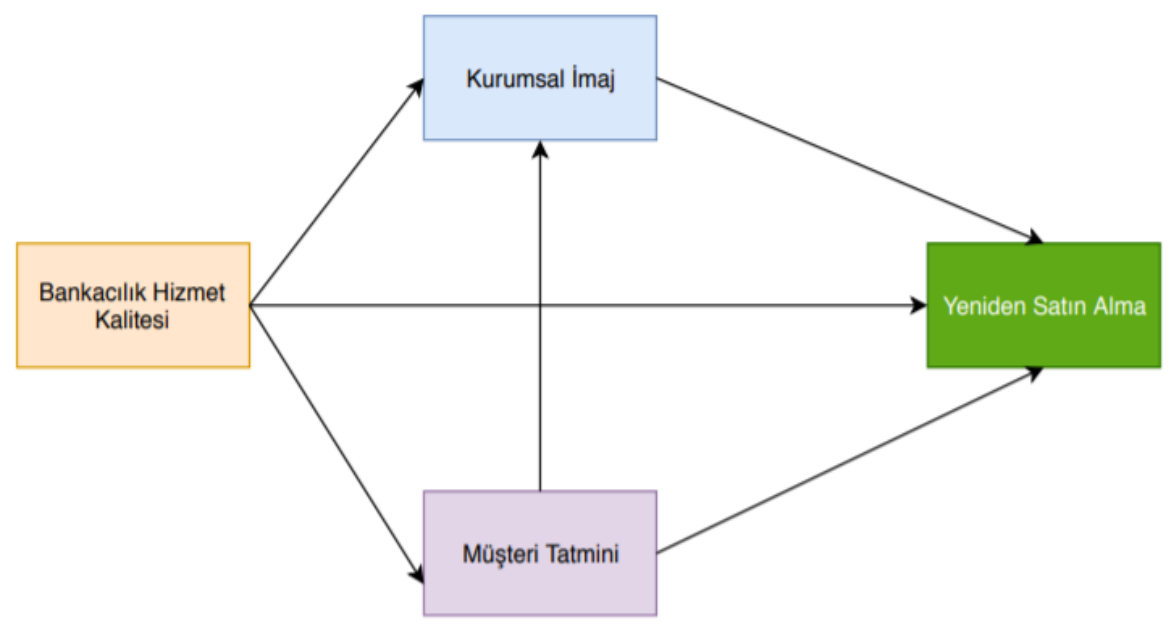

Şekil 1. Araştırmanın Modeli

Bankaların finansal performansına etki eden faktörlerden biri de hizmet kalitesidir. Çünkü hizmet kalitesinden memnun olan müşteriler tekrar satın alma davranışı gösterecek ve bankanın sadık müşterileri haline gelebilecektir. Neticede bu durum bankaların rekabet gücünü ve finansal performansını da artıracaktır. $\mathrm{Bu}$ nedenle bu çalışmada hizmet kalitesinin müşteri memnuniyeti, kurumsal imaj ve tekrar satın alma davranışı üzerindeki etkisi araştırılmıştır. Kuramsal çalışma ve literatür taraması neticesinde aşağıdaki hipotezler kurulmuştur:

H1: Bankacılık hizmet kalitesi kurumsal imajı anlamlı olarak etkiler.

H2: Bankacılık hizmet kalitesi müşteri tatminini anlamlı olarak etkiler.

H3: Bankacılık hizmet kalitesi tekrar satın alma davranışını anlamlı olarak etkiler.

H4: Müşteri tatmini kurumsal imajı anlamlı olarak etkiler.

H5: Müşteri tatmini tekrar satın alma davranışını anlamlı olarak etkiler.

H6: Kurumsal imaj tekrar satın alma davranışını anlamlı olarak etkiler.

H7: Bankacılık hizmet kalitesi kamu ve özel sektör bankaları arasında anlamlı farklılık göstermektedir.

H7a: Heveslilik boyutu kamu ve özel sektör bankaları arasında anlamlı farklılık göstermektedir.

H7b: Empati boyutu kamu ve özel sektör bankaları arasında anlamlı farklılık göstermektedir.

H7c: Güvenilirlik boyutu kamu ve özel sektör bankaları arasında anlamlı farklılık göstermektedir.

H7d: Güven boyutu kamu ve özel sektör bankaları arasında anlamlı farklılık göstermektedir.

H7e: Somut özellikler boyutu kamu ve özel bankaları sektör arasında anlamlı farklılık göstermektedir.

H8: Kurumsal imaj kamu ve özel sektör bankaları arasında anlamlı farklılık göstermektedir.

H9: Müşteri tatmini kamu ve özel sektör bankaları arasında anlamlı farklılık göstermektedir.

H10: Tekrar satın alma kamu ve özel sektör bankaları arasında anlamlı farklılık göstermektedir.

\section{2. Araştırmanın Ölçekleri}

Hizmet kalitesi ölçeği Parasuraman vd. (1985) tarafından geliştirilmiştir. Dolayısıyla araştırmada Parasuraman vd. tarafından geliştirilen ölçek kullanılmıştır. Ölçeğin Türkçe maddeleri ise Yücel (2013) çalışmasından alınmıştır. Müşteri tatmini ve tekrar satın alma niyeti ölçekleri Bülbül vd. (2012) çalışmasından alınmıştır. Kurumsal imaj ölçeği ise Bayol vd. (2000) tarafından geliştirilmiştir. Ölçeğin Türkçe maddeleri Kalyoncuoğlu ve Faiz (2016) çalışmalarından alınmıştır. 


\section{3. Araştırmanın Örneklemi}

Araştırma verileri toplanırken kolayda örnekleme yöntemi kullanılmıştır. Araştırmada 5'li likert ölçeği kullanılmıştır. Katılımcılardan katılma düzeylerini belirtmeleri istenmiştir. Sorulara 1: Kesinlikle katılmıyorum, 2: Katılmıyorum, 3: Ne katılıyorum ne katılmiyorum, 4: Katıliyorum ve 5: Kesinlikle katılıyorum şeklinde cevap vermeleri istenmiştir.

Araştırmanın örneklemini Kastamonu ilinde ikamet etmekte olup bankacılık hizmeti alan 867 banka müşterisi oluşturmaktadır. 982 banka müşterisinden anket ile veri toplanmıştır. 115 anket cevaplayıcılar tarafından eksik doldurulduğundan yani katılımcıların cevap vermedikleri sorular bulunduğundan analize dâhil edilmemiştir. Neticede 867 anketten elde edilen verilerle analizler yapılmıştır.

\section{BULGULAR}

Bu bölümde ilk olarak ölçeklerin yapı geçerliği ve güvenilirlik testi yapılarak, doğrulayıcı faktör analizi ve korelasyon testi sonuçlarına yer verilmiştir. İkinci kısımda ise yapısal eşitlik modeli ve $\mathrm{T}$ testi sonuçları yer almaktadır.

\subsection{Demografik Bulgular}

Katılımcıların bazı demografik özellikleri Tablo 2'de sunulmuştur.

Tablo 2. Demografik Bulgular

\begin{tabular}{|l|l|l|}
\hline Cinsiyet & Frekans & Yüzde \% \\
\hline Kadın & 299 & 34,5 \\
\hline Erkek & 568 & 65,5 \\
\hline Toplam & 867 & 100,0 \\
\hline Yaş & Frekans & Yüzde \\
\hline $18-24$ & 248 & 28,6 \\
\hline $25-34$ & 249 & 28,7 \\
\hline $35-44$ & 225 & 26,0 \\
\hline $45-54$ & 96 & 11,1 \\
\hline 55 ve üzeri & 49 & 5,7 \\
\hline Toplam & 867 & 100,0 \\
\hline Eğitim Durumu & Frekans & Yüzde \\
\hline İlköğretim & 46 & 5,3 \\
\hline Ortaöğretim & 199 & 23,0 \\
\hline Önlisans & 151 & 17,4 \\
\hline Lisans & 395 & 45,6 \\
\hline Lisansüstü & 58 & 6,7 \\
\hline Total & 849 & 97,9 \\
\hline Cevapsız & 18 & 2,1 \\
\hline Toplam & 867 & 100,0 \\
\hline Aylık Gelir & Frekans & Yüzde \\
\hline 2000 altı & 248 & 28,6 \\
\hline $2000-3999$ & 325 & 37,5 \\
\hline $4000-5999$ & 191 & 22,0 \\
\hline $6000-7999$ & 52 & 6,0 \\
\hline 8000 üstü & 31 & 3,6 \\
\hline Total & 847 & 97,7 \\
\hline Cevapsiz & 20 & 2,3 \\
\hline Toplam & 867 & 100,0 \\
\hline Meslek & Frekans & Yüzde \\
\hline Özel sektör çalısan & 220 & 25,4 \\
\hline & & \\
\hline
\end{tabular}




\begin{tabular}{|l|l|l|} 
Kamu çalışan & 205 & 23,6 \\
\hline Özel sektör yönetici & 34 & 3,9 \\
\hline Kamu yönetici & 6 &, 7 \\
\hline Akademisyen / öğretmen & 45 & 5,2 \\
\hline Öğrenci & 203 & 23,4 \\
\hline Esnaf / şirket sahibi & 111 & 12,8 \\
\hline Ev hanımı & 19 & 2,2 \\
\hline Serbest meslek (Avukat, eczacı vb.) & 24 & 2,8 \\
\hline Toplam & 867 & 100,0 \\
\hline
\end{tabular}

Araştırmaya katılan banka müşterilerinin 249'u 25-34, 248'i 18-24, 225'i 35-44, 96'sı 45-54 arasında ve 49'u da 55 ve üzeri yaşa sahiptir. Katılımcıların \% 83,3'ü 45 yaşın altındadır. Bu nedenle araştırma örneklemini genç ve orta yaş kesimi oluşturmaktadır.

Katılımcların 568'i erkek ve 299'u kadındır. 395'i lisans, 199'u orta öğretim, 151'i ön lisans, 58'i lisansüstü ve 46 'sı da ilköğretim seviyesinde eğitime sahiptir. 18 katılımcı eğitim durumu ile ilgili soruyu cevapsız bırakmıştır.

Araştırmaya katılan banka müşterilerinin 325'i 2.000TL-3.999TL arası, 248'i 2.000 lira altı, 191'i 4.000TL5.999TL arası 52'si 6.000TL-7.999TL arası ve 31'i de 8.000 lira ve üzeri aylık gelire sahiptir. 20 katılımcı aylık gelir ile ilgili soruyu cevapsız bırakmıştır. Katılımcıların \%67,7'si aylık 4.000 liranın altında gelire sahiptir.

Katılımcıların 220'si özel sektör çalışanı, 205'i kamu sektörü çalışanı olarak görev yapmakta olup 11'i esnaf ya da şirket sahibidir. 45'i akademisyen ya da öğretmen olarak görev yapmakta, 34'ü özel sektörde yönetici olarak çalışmakta, 24'ü serbest meslek (avukat, eczacı vb.) ile iştigal etmektedir. 19'u ev hanımıdır, 6'sı kamu sektöründe yöneticilik yapmaktadır ve 203'ü de öğrencidir. Araştırma sorusunda emekli seçeneği de olmakta, ancak araştırmaya katılanlar arasında emekli bulunmamaktadır.

Katılımcılara ayrıca en çok hizmet aldıkları bankanın hangisi olduğu sorusu sorulmuştur. En çok hizmet alınan bankaya ilişkin bulgular Tablo 3'te verilmiştir.

Tablo 3. En Çok Hizmet Alınan Banka Bilgileri

\begin{tabular}{|l|l|l|}
\hline En Çok Çalışılan Banka & Frekans & Yüzde \\
\hline Ziraat Bankası & 340 & 39,2 \\
\hline Vakıfbank & 109 & 12,6 \\
\hline Halkbank & 66 & 7,6 \\
\hline Garanti & 75 & 8,7 \\
\hline Akbank & 49 & 5,7 \\
\hline Albaraka Türk & 2 &, 2 \\
\hline Denizbank & 13 & 1,5 \\
\hline Finansbank & 25 & 2,9 \\
\hline İNG & 16 & 1,8 \\
\hline İş Bankası & 71 & 8,2 \\
\hline Kuveyt Türk & 9 & 1,0 \\
\hline Şekerbank & 1 &, 1 \\
\hline TEB & 26 & 3,0 \\
\hline Türkiye Finans & 2 &, 2 \\
\hline Yapı ve Kredi & 63 & 7,3 \\
\hline Toplam & 867 & 100,0 \\
\hline
\end{tabular}

Katılımcıların en çok hizmet aldıkları bankaya ilişkin bulgular ise şu şekildedir: 340'i en çok T. C. Ziraat Bankasından, 109'u Türkiye Vakıflar Bankasından, 75'i Türkiye Garanti Bankasından, 71'i Türkiye İş 


\section{F. Day1 - B. Yıldız 12/1 (2020) 1-17}

Bankasından, 66'sı Türkiye Halkbankası'ndan, 63'ü Yapı ve Kredi Bankasından, 49'u Akbank'tan, 26'sı Türk Ekonomi Bankasından, 25'i QNB Finansbank'tan, 16'sı ING'den, 13'ü Denizbank'tan, 9'u Kuveyt Türk Katılım Bankasından, 2'si Albaraka Türk Katılım Bankasından, 2'si Türkiye Finans Katılım Bankasından ve 1'i de Şekerbank'tan hizmet almaktadır. Katılımcıların 514'ü en çok bankacilık hizmetini kamu bankalarından almakta olup 353'ü ise özel bankalardan almaktadır.

\section{2. Ölçeklerin Yapı Geçerliği ve Güvenilirliği}

Ölçeklerin yapı geçerliği ve güvenilirliği test edilmeden önceden normal dağılım ön koşulunu sağlayıp sağlamadıklarını tespit edebilmek için basıklık ve çarpıklık değerlerine bakılmıştır. Bütün maddelerin basıklık ve çarpıklık değerlerinin -1 ile +1 arasında değerler aldığı görülmüştür. Bu nedenle veriler normal dağılım göstermektedir.

Araştırmada kullanılan ölçeklerin daha önceki çalışmalarda Türkçe yapı geçerliği ve güvenilirliği test edilmiştir. Bu nedenle araştırma modeli analiz edilmeden önce doğrulayıcı faktör analizi (DFA) ve güvenilirlik analizleri yapılmıştır. DFA sonucu elde edilen uyum iyiliği değerleri Tablo 4'de sunulmuştur.

Tablo 4. DFA Uyum İyiliği Değerleri

\begin{tabular}{|l|c|c|c|c|c|c|c|}
\hline Değişkenler & CMIN & DF & CMIN/DF & GFI & CFI & SRMR & RMSEA \\
\hline Banka Hizmet Kalitesi 2 düzey & 684,038 & 184 & 3,718 & 0,928 & 0,919 & 0,0449 & 0,056 \\
\hline Kurumsal İmaj & 7,117 & 4 & 1,779 & 0,997 & 0,997 & 0,0143 & 0,03 \\
\hline Müşteri Tatmini & 0 & 0 & - & 1 & 1 & 0,0000 & - \\
\hline Tekrar Satın Alma & 0 & 0 & - & 1 & 1 & 0,0000 & - \\
\hline
\end{tabular}

Analiz sonucu ölçeklerin kabul edilebilir uyum iyiliği değerlerini sağladığı tespit edilmiştir (Schermelleh vd., 2003). Müş̧eri tatmini ve tekrar satın alma ölçekleri 3 maddeden oluştuğundan, CMIN ve DF değerleri sıfır olarak elde edilmiştir. Bu ölçekler için GF ve CFI değerleri 1 olduğundan ve SRMR değeri 0,0000 olarak elde edildiğinden iyi uyum gösterdikleri varsayılmaktadır.

DFA sonucu faktör yükleri banka hizmet kalitesi ölçeğinin heveslilik boyutu için 0,62 ile 0,78 arasında; empati boyutu için 0,52 ile 0,63 arasında; somut özellikler boyutu için 0,66 ile 0,72 arasında; güvence boyutu için 0,62 ile 0,69 arasında ve güvenilirlik boyutu için 0,59 ile 0,65 arasında elde edilmiştir. Faktör yükleri kurumsal imaj boyutu için 0,55 ile 0,72 arasında elde edilmiştir. Müşteri tatmini boyutu için 0,60 ile 0,76 arasında ve tekrar satın alma boyutu için 0,62 ile 0,83 arasında tespit edilmiştir.

DFA'dan sonra korelasyon ve güvenilirlik analizi yapılmıştır. Korelasyon ve güvenilirlik analizi bulguları Tablo 5'de verilmiştir.

Tablo 5. Korelasyon ve Güvenilirlik Analizi

\begin{tabular}{|l|c|c|c|c|c|c|}
\hline Değişkenler & Ortalama & $\begin{array}{c}\text { Standart } \\
\text { Sapma }\end{array}$ & $\begin{array}{c}\text { Hizmet } \\
\text { Kalitesi }\end{array}$ & $\begin{array}{c}\text { Kurumsal } \\
\text { İmaj }\end{array}$ & $\begin{array}{c}\text { Müşteri } \\
\text { Tatmini }\end{array}$ & $\begin{array}{c}\text { Tekrar Satın } \\
\text { Alma }\end{array}$ \\
\hline Hizmet Kalitesi & 3,5850 &, 60879 & $(, 904)$ & & & \\
\hline Kurumsal İmaj & 3,6938 &, 72804 &, $705^{* *}$ & $(, 780)$ & & \\
\hline Müşteri Tatmini & 3,5293 &, 80796 &, $664^{* *}$ &, $686^{* *}$ & $(, 744)$ & \\
\hline Tekrar Satın Alma & 3,5948 &, 90870 &, $597^{* *}$ &, $631^{* *}$ &, $676^{* *}$ & $(, 793)$ \\
\hline
\end{tabular}

Korelasyon analizi sonucu değişkenler arasında 0,01 anlamlılık düzeyinde aynı yönde ve orta seviyede anlamlı ilişki olduğu tespit edilmiştir. Güvenilirlik analizi sonucu da ölçeklerin alfa katsayısı değerleri 0,70'in üzerinde elde edilmiş olduğundan güvenilir olduğu bulgusuna ulaşılmıştır. Ölçeklerin ortalama değerlerine bakıldığında müşterilerin banka hizmet kalitesinden genel olarak memnun olduğu görülmektedir. 


\subsection{Yapısal Eşitlik Modeli}

Araştırma modelini test etmek amacıyla yapısal eşitlik modeli kurularak analiz edilmiştir. Model Şekil 2'de, modelin uyum iyiliği değerleri Tablo 4 'de, analiz sonuçları ise Tablo 5 'de verilmiştir.

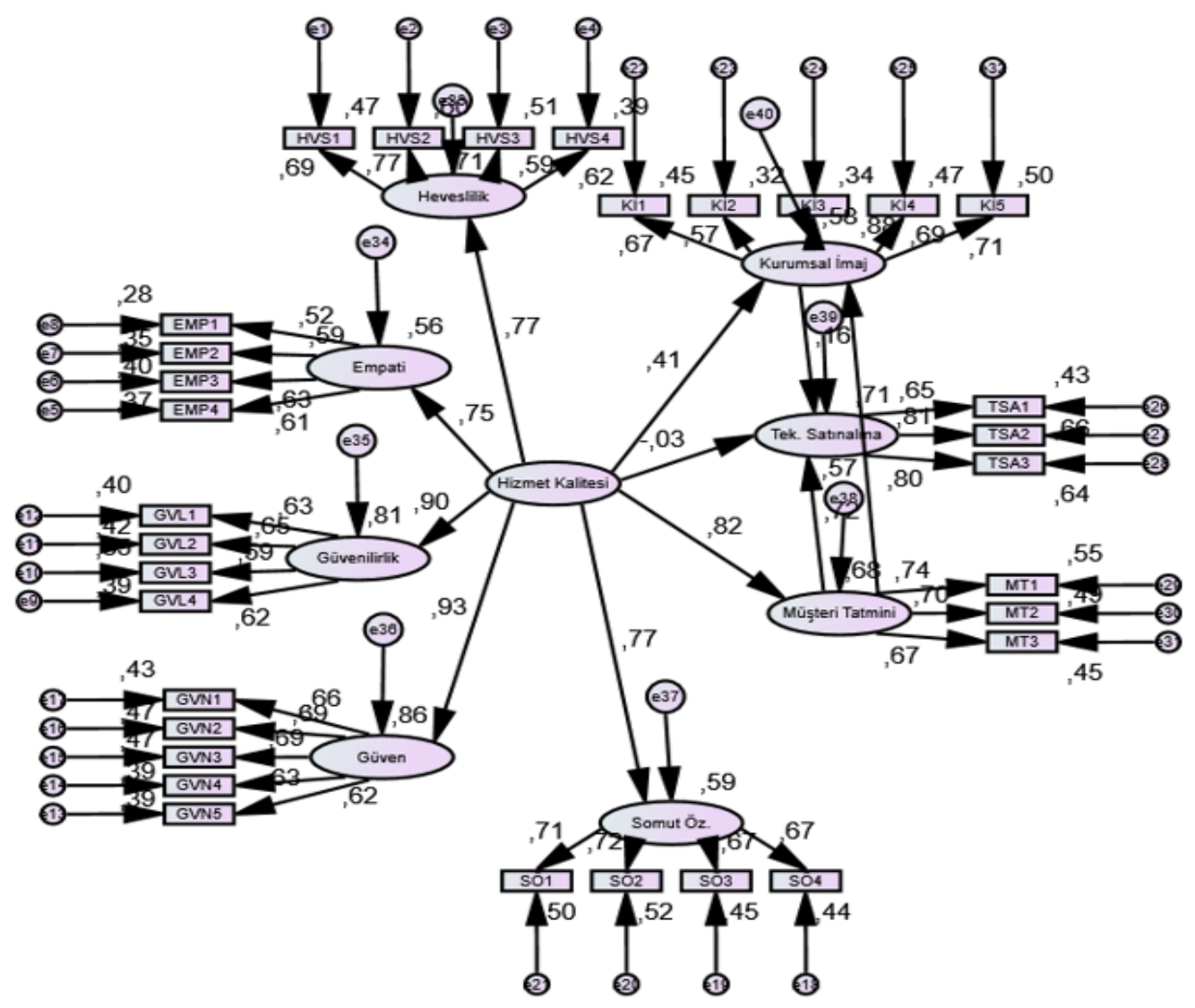

Şekil 2. Yapısal Eşitlik Modeli

Şekil 2'de görüleceği üzere banka hizmet kalitesinin kurumsal imaj, tekrar satın alma ve müşteri tatmini üzerindeki etkisi analiz edilmiştir. Müşteri tatmininin, tekrar satın alma ve kurumsal imaj üzerindeki etkisi analiz edilmiştir. Kurumsal imajın da tekrar satın alma üzerindeki etkisi analiz edilmiştir.

Tablo 6. Yapısal Eşitlik Modeli Uyum İyiliği

\begin{tabular}{|l|c|c|c|c|c|c|c|}
\hline Değişken & CMIN & DF & CMIN/DF & GFI & CFI & SRMR & RMSEA \\
\hline Yapısal Eşitlik Modeli & 1277,812 & 453 & 2,821 & 0,913 & 0,924 & 0,0414 & 0,046 \\
\hline
\end{tabular}

Tablo 6 verilen analiz sonuçların incelendiğinde yapısal eşitlik modelinin kabul edilebilir uyum iyiliği kriterlerini sağladığı tespit edilmiştir.

Tablo 7. Yapısal Eşitlik Modeli Analiz Sonuçları

\begin{tabular}{|c|c|c|c|c|c|c|}
\hline \multicolumn{3}{|c|}{ Test Edilen Yol } & \multirow{2}{*}{$\begin{array}{c}\begin{array}{c}\text { Standardize } \\
\text { Edilmiş } \\
\text { Tahmin }\end{array} \\
0,823\end{array}$} & \multirow{2}{*}{$\begin{array}{c}\begin{array}{c}\text { Standart } \\
\text { Hata }\end{array} \\
0,068\end{array}$} & \multirow{2}{*}{$\begin{array}{c}\text { Kritik } \\
\text { Oran }\end{array}$} & \multirow{2}{*}{$\begin{array}{l}\mathbf{P} \\
* * *\end{array}$} \\
\hline Müşteri Tatmini & <--- & Hizmet Kalitesi & & & & \\
\hline Kurumsal İmaj & $<--$ & Hizmet Kalitesi & 0,408 & 0,084 & 5,48 & $* * *$ \\
\hline Kurumsal İmaj & $<<--$ & Müşteri Tatmini & 0,572 & 0,074 & 7,348 & $* * *$ \\
\hline Tekrar Satın Alma & $<--$ & Hizmet Kalitesi & $-0,033$ & 0,112 & $-0,342$ & 0,732 \\
\hline Tekrar Satın Alma & $<--$ & Kurumsal İmaj & 0,16 & 0,185 & 0,894 & 0,371 \\
\hline Tekrar Satın Alma & $<--$ & Müşteri Tatmini & 0,725 & 0,16 & 4,44 & $* * *$ \\
\hline
\end{tabular}




\section{F. Dayı - B. Yildız 12/1 (2020) 1-17}

Yapısal eşitlik modelinin analiz sonucunda banka hizmet kalitesinin müşteri tatminini ve kurumsal imajı pozitif yönde anlamlı olarak etkilediği bulgusuna ulaşılmıştır. Müşteri tatmininin de kurumsal imaj ve tekrar satın almayı pozitif yönde anlamlı olarak etkilediği tespit edilmiştir. Hizmet kalitesi ve kurumsal imaj tekrar satın alma niyetini anlamlı olarak etkilememiştir. Hizmet kalitesinin müşteri tatmini üzerindeki etkisinde katsayı tahmin değeri 0,823 olarak bulunmuştur. Bu bulgu hizmet kalitesinin 1 birim artış göstermesi durumunda müşteri tatmininin 0,823 birim artış göstereceği anlamına gelmektedir. Müşteri tatmini için hizmet kalitesinin çok büyük bir öneme sahip olduğu görülmektedir. Hizmet kalitesinin kurumsal imaj üzerindeki etkisinde katsayı tahmin değeri 0,408 olarak bulunmuştur. Bu bulgu hizmet kalitesinin 1 birim artış göstermesi durumunda kurumsal imajın 0,408 birim artış göstereceği anlamına gelmektedir. Müşteri tatmininin kurumsal imaj üzerindeki etkisinde katsayı tahmin değeri 0,572 olarak elde edilmiştir. Bu bulgu müşteri tatmininin 1 birim artış göstermesi halinde kurumsal imaj algısının 0,572 birim artış göstereceği anlamına gelmektedir. Kurumsal imaj algısı için tatmin olmuş müşterilerin önem arz ettiği görülmektedir. Müşteri tatmininin tekrar satın alma üzerindeki etkisinde katsayı tahmin değeri 0,725 olarak bulunmuştur. Bu bulgu müşteri tatmininin 1 birim artış göstermesi durumunda tekrar satın alma niyetinin 0,725 birim artış göstereceği anlamına gelmektedir. Tüketicilerin tekrar satın alma davranışında müşteri tatmininin çok büyük bir öneme sahip olduğu görülmektedir.

Analiz neticesinde H1, H2, H4 ve H5 hipotezleri desteklenmiştir. H3 ve H6 hipotezleri desteklenememiştir.

\subsection{Farklılık Analizleri}

Değişkenlerin kamu ve özel sektör arasında anlamlı farklılık gösterip göstermediğini test edebilmek için T testi yapılmıştır. Analiz sonuçları Tablo 8' da verilmiştir.

Tablo 8. Bağımsız Örneklem T Testi

\begin{tabular}{|c|c|c|c|c|c|c|}
\hline & \multicolumn{2}{|c|}{$\begin{array}{c}\text { Levene'nin } \\
\text { Varyans Eşitliği } \\
\text { Testi } \\
\end{array}$} & \multicolumn{3}{|c|}{ Ortalamaların Eşitliği için t-testi } \\
\hline & & $\mathrm{F}$ & Sig. & $\mathrm{t}$ & $\mathrm{df}$ & Sig. (2-kuyruk) \\
\hline \multirow{2}{*}{$\begin{array}{l}\text { Hizmet } \\
\text { Kalitesi }\end{array}$} & Varsayılan eşitlikler & ,002 & 962 & $-2,908$ & 865 & ,004 \\
\hline & Varsayılmayan eşitlikler & & & $-2,906$ & 754,238 & ,004 \\
\hline \multirow{2}{*}{ Heveslilik } & Varsayılan eşitlikler & 643 & 423 & $-2,755$ & 865 & ,006 \\
\hline & Varsayılmayan eşitlikler & & & $-2,772$ & 772,801 & ,006 \\
\hline \multirow[t]{2}{*}{ Empati } & Varsayılan eşitlikler & 036 & 849 & $-1,557$ & 865 &, 120 \\
\hline & Varsayılmayan eşitlikler & & & $-1,555$ & 752,133 & 120 \\
\hline \multirow[t]{2}{*}{ Güvenilirlik } & Varsayılan eşitlikler & 1,463 & ,227 & $-2,194$ & 865 & ,029 \\
\hline & Varsayılmayan eşitlikler & & & $-2,214$ & 780,028 & 027 \\
\hline \multirow[t]{2}{*}{ Güven } & Varsayılan eşitlikler & 202 & 653 & $-1,932$ & 865 & ,054 \\
\hline & Varsayılmayan eşitlikler & & & $-1,913$ & 729,689 & ,056 \\
\hline \multirow{2}{*}{$\begin{array}{l}\text { Somut } \\
\text { Özellikler }\end{array}$} & Varsayılan eşitlikler & 477 & ,490 & $-3,011$ & 865 & ,003 \\
\hline & Varsayılmayan eşitlikler & & & $-3,019$ & 763,242 & ,003 \\
\hline \multirow{2}{*}{$\begin{array}{l}\text { Kurumsal } \\
\text { İmaj }\end{array}$} & Varsayılan eşitlikler & ,743 & ,389 & $-1,514$ & 865 &, 130 \\
\hline & Varsayılmayan eşitlikler & & & $-1,527$ & 778,174 & 127 \\
\hline \multirow{2}{*}{$\begin{array}{l}\text { Müşteri } \\
\text { Tatmini }\end{array}$} & Varsayılan eşitlikler & 1,010 & 315 & $-2,717$ & 865 & ,007 \\
\hline & Varsayılmayan eşitlikler & & & $-2,735$ & 774,294 & ,006 \\
\hline \multirow{2}{*}{$\begin{array}{l}\text { Tekrar } \\
\text { Satın Alma }\end{array}$} & Varsayılan eşitlikler &, 535 & , 465 & $-2,995$ & 865 & ,003 \\
\hline & Varsayılmayan eşitlikler & & & $-2,988$ & 751,043 & ,003 \\
\hline
\end{tabular}

Banka genel hizmet kalitesi, heveslilik, güvenilirlik, somut özellikler boyutları, müşteri tatmini ve tekrar satın alma niyetinin kamu ve özel sektör bankalarına göre anlamlılık düzeyi 0,05'in altında bulunduğundan anlamlı farklılık gösterdiği tespit edilmiştir. Farklılığın yönü için ortalama değerlere bakılmıştır. Ortalama değerlere ilişkin bulgular Tablo 9'de verilmiştir. 


\section{F. Day1 - B. Yıldız 12/1 (2020) 1-17}

Tablo 9. T Testi Ortalama Değerler

\begin{tabular}{|l|l|c|c|c|c|}
\hline \multicolumn{2}{|l}{} & N & Ortalama & Std. Sapma & Std. Hata Ort. \\
\hline \multirow{3}{*}{ Genel Hizmet Kalitesi } & Kamu & 514 & 3,5354 &, 60499 &, 02668 \\
\cline { 2 - 6 } & Özel & 353 & 3,6573 &, 60793 &, 03236 \\
\hline \multirow{2}{*}{ Heveslilik } & Kamu & 514 & 3,5274 &, 85635 &, 03777 \\
\cline { 2 - 6 } Empati & Özel & 353 & 3,6883 &, 82820 &, 04408 \\
\hline \multirow{2}{*}{ Güvenilirlik } & Kamu & 514 & 3,2048 &, 80147 &, 03535 \\
\cline { 2 - 6 } & Özel & 353 & 3,2914 &, 80881 &, 04305 \\
\hline \multirow{2}{*}{ Güven } & Kamu & 514 & 3,5841 &, 74317 &, 03278 \\
\cline { 2 - 6 } & Özel & 353 & 3,6946 &, 70775 &, 03767 \\
\hline \multirow{2}{*}{ Somut Özellikler } & Kamu & 514 & 3,5602 &, 72930 &, 03217 \\
\cline { 2 - 6 } & Özel & 353 & 3,6598 &, 76952 &, 04096 \\
\hline \multirow{2}{*}{ Kurumsal İmaj } & Kamu & 514 & 3,7943 &, 75951 &, 03350 \\
\cline { 2 - 6 } & Özel & 353 & 3,9515 &, 74933 &, 03988 \\
\hline \multirow{2}{*}{ Müşteri Tatmini } & Kamu & 514 & 3,6628 &, 74054 &, 03266 \\
\cline { 2 - 6 } & Özel & 353 & 3,7389 &, 70806 &, 03769 \\
\hline \multirow{2}{*}{ Tekrar Satın Alma } & Kamu & 514 & 3,4678 &, 81681 &, 03603 \\
\cline { 2 - 6 } & Özel & 353 & 3,6189 &, 78748 &, 04191 \\
\hline & Kamu & 514 & 3,5185 &, 90037 &, 03971 \\
\cline { 2 - 6 } & Özel & 353 & 3,7058 &, 91061 &, 04847 \\
\hline
\end{tabular}

Ortalama değerlere bakıldığında; genel bankacılık hizmet kalitesi, heveslilik, güvenilirlik ve somut özellikler boyutları ile müşteri tatmini ve tekrar satın alma ölçeklerinin özel sektör ortalama değerleri kamu bankalarının ortalama değerlerinden daha yüksektir. Bu bulgular, bankaların genel hizmet kalitesi bakımından özel bankalarının hizmet kalitesinin kamu bankalarından anlamlı olarak farklı olduğu ve özel bankaların hizmet kalitesi seviyesinin kamu bankalarından daha yüksek olduğunu göstermektedir. Müşteriler özel bankaların hizmet kalitesinin daha yüksek olduğu görüşüne sahiptirler. Ayrıca müşterilerin özel bankalardan tekrar hizmet satın alma niyetlerinin daha yüksek olduğunu görülmektedir.

Yapılan analiz sonuçlarına göre H7, H7a, H7c, H7e, H9 ve $\mathrm{H} 10$ hipotezleri desteklenmiştir. H7b, H7d ve H8 hipotezleri ise desteklenememiştir.

\section{SONUÇ VE DEĞERLENDİRME}

Bu çalışmada bankacılık hizmet kalitesinin kurumsal imaj, müşteri tatmini, tekrar satın alma niyeti üzerindeki etkisi; müşteri tatminin kurumsal imaj ve tekrar satın alma üzerindeki etkisi ve kurumsal imajın tekrar satın alma üzerindeki etkisi araştırılmıştır. Ayrıca bankacılık hizmet kalitesi, müşteri tatmini, kurumsal imaj ve tekrar satın alma niyetinin kamu ve özel sektör arasında anlamlı farklılık gösterip göstermediği incelenmiştir. Bu amaçla Kastamonu ilinde ikamet etmekte olan bankacilık hizmeti alan 867 banka müşterisinden anket ile veri elde edilmiştir. Öncelikle araştırmada kullanılan ölçeklerin yapı geçerliği ve güvenilirliğini test etmek amacıyla DFA ve güvenilirlik analizleri yapılmıştır. Araştırma hipotezleri kurulan yapısal eşitlik modelinin analizi ile test edilmiştir. Yapısal eşitlik modelinin analizi neticesinde hizmet kalitesinin müşteri tatmini ve kurumsal imajı pozitif yönde anlamlı olarak etkilediği tespit edilmiştir. Bu bulgu müşteri tatmini sağlamayı hedefleyen bankaların hizmet kalitesine azami önem vermeleri gerektiğini göstermektedir. Günümüzde bankacılık sektöründe sunulan ürünlerin birbirine benzerliği ve kredi vb. ürünlerin faiz oranlarının da yakın değerler alması nedeniyle müşteri memnuniyeti ve tatminini sağlayabilmek için bankaların sunmuş oldukları hizmetin kalitesi ön plana çıkmaktadır. Dolayısıyla banka tercihinde hizmet kalitesi rekabet edebilirlikte çok ciddi bir rol oynamaktadır. Hizmet kalitesi aynı zamanda kurumsal imajı da anlamlı olarak etkilemiştir. Tüketicinin gözünde yerleşmiş olan kurumsal imaj da banka tercihinde önemli bir yere sahip olmaktadır. Bu nedenle hem müşteri tatmini hem de kurumsal imaj için bankaların sundukları hizmet kalitesi önem arz etmektedir. Analiz sonucunda ayrıca müşteri tatmininin kurumsal imajı ve tekrar satın alma niyetini pozitif yönde anlamlı olarak etkilediği bulgusuna ulaşılmıştır. Hizmet kalitesinden tatmin olmuş müşterilerin 


\section{F. Day1 - B. Yıldız 12/1 (2020) 1-17}

kurumsal imaj algılarında da farklılık meydana gelmektedir. Bu da tekrar hizmet satın alma isteğini olumlu olarak etkilemektedir.

Araştırma sonucunda bankacilık hizmet kalitesinin, müşteri tatmininin ve tekrar satın alma niyetinin özel bankalar lehine, kamu ve özel bankalar arasında anlamlı farklılık gösterdiği bulgusu elde edilmiştir. Bu bulgular tüketicilerin özel bankaların hizmet kalitesinden daha fazla memnun olduklarını göstermektedir. Tüketiciler özel bankalarla çalıştıklarında daha fazla tatmin olmaktadırlar ve özel bankalardan tekrar hizmet satın alma niyetleri daha yüksektir. Kamu ve özel sektör bankaları arasında da ciddi rekabet bulunmaktadır. Yapılan çalışma müşterilerin özel bankalardan daha memnun olduğunu göstermektedir. Bu nedenle kamu bankaları müşteri memnuniyetini elde etmek ve sadık müşteriler elde edebilmek için hizmet kalitesine yükseltecek çalışmalara ağırlık vermelidirler. Çiçek ve Doğan (2009) Niğde'de yaptıkları bir araştırmada banka müşterilerinin kamu bankalarının hizmet kalitesinden daha memnun olduğunu bulgulamışlardır. Bu bulgu araştırmanın sonuçları ile uyuşmamaktadır. Bu nedenle hizmet kalitesinin şehirlere ve hatta şubelere göre farklılık gösterebileceği söylenebilecektir. Çünkü müşteriler yaşamış oldukları ilin şubesinde görev yapan personel ile iletişim halindedirler. Günümüz bankacılık hizmetlerinde müşteriler bireysel ilgi beklemektedir. Bu nedenle sık sık müşteri ziyaretlerinin gerçekleştirilmesi, şube dizaynlarının her kesimden müşteriye hitap edecek şekilde ve ferah bir ortam oluşturularak yapılması, kalabalık ve büyük şubelerde beklemekte olan müşteriler için küçük ikramların yapılması hizmet kalitesini artıracak unsurlar olabilecektir.

$\mathrm{Bu}$ araştırmanın bazı kısıtları bulunmaktadır. Araştırmanın en önemli kısıtı sadece Kastamonu ilinde ikamet eden banka müşterilerini kapsıyor olmasıdır. Diğer kısıtı ise anket ile toplanan verilerle yapılmış olması yani soruların ankette katılımcılara yöneltilenler ile sınırlı olmasıdır. Ayrıca katılımcıların anket sorularına doğru cevap verdiği varsayılmıştır. Çalışmanın büyükşehirlerde daha büyük örneklem ile yapılmasının literatüre katkı sağlaması beklenmektedir.

\section{KAYNAKÇA}

Afşar, M. (2011). Küresel Kriz ve Türk Bankacıllk Sektörüne Yansımaları. Eskişehir Osmangazi Üniversitesi İ̈BF Dergisi, 6(2), 143-171.

Aktaş, H. ve Kargın, M. (2007). Türk Bankacılık Sektöründeki Yabancı ve Ulusal Bankaların Finansal Oranlar Açısından Karşılaştırılması. Celal Bayar Üniversitesi İ.̇.B.F. Yönetim ve Ekonomi Dergisi, 14(2), 32-45.

Albayrak, Y. E. ve Erkut, H. (2005). Banka performans değerlendirmede analitik hiyerarşi süreç yaklaşımı. İTÜ Dergisi, 4(6), 47-58.

Aldlaigan, A. H. and Buttle, F. A. (2002). SYSTRA-SQ: A New Measure of Bank Service Quality. International Journal of Service Industry Management, 13(4), 362-381.

Altan, Ş. ve Atan, M. (2004). Bankacılık Sektöründe Toplam Hizmet Kalitesinin Servqual Analizi İle Ölçümü. Gazi Üniversitesi İktisadi ve İdari Bilimler Fakültesi Dergisi, 1, 17-32.

Arı, E. ve Yılmaz, V. (2015). Banka Hizmet Kalitesi Boyutları İle Banka Sadakati Arasındaki İlişkilerin Servqual Ve Yapısal Eşitlik Modeli İle İncelenmesi: İ.̇̇.B.F Öğrencileri Üzerine Bir Uygulama. Süleyman Demirel Üniversitesi İktisadi ve İdari Bilimler Fakültesi Dergisi, 20(3).

Arı, E., Yılmaz, V. ve Dışbudak, E. N. (2015). Servqual Hizmet Kalitesi Boyutları Servqual Hizmet Kalitesi Boyutları Üzerine Bir Yapısal Eşitlik Modeli: Ankara Örneği. Finans Politik E Ekonomik Yorumlar, 52(609), 23-31.

Athanassopoulos, A. D. (1997). Service quality and operating efficiency synergies for management control in the provision of financial services: Evidence from Greek Bank Branches. European Journal of Operational Research(98), 300-313.

Bahia, K. and Nantel, J. (2000). A reliable and valid measurement scale for the perceived service quality of banks. Internatıonal Journal of Bank Marketing, 18 (2): 84-91.

Bayol, M.P., Foye, A., Tellier, C. and Tenenhaus, M. (2000). Use of PLS Path Modeling to Estimate the European Consumer Satisfaction Index (ECSI) Model. Statistica Applicata, 12 (3): 361-375.Berry, L. L., Parasuraman, A., \& Zeithaml, V. A. (1994). Improving service quality in America: Lessons learned. Academy of Management Executive, 8(2), 32-45. 


\section{F. Dayı - B. Yildız 12/1 (2020) 1-17}

Bloemer, J., Ruyter, K. D. and Peeters, P. (1998). Investigating drivers of bank loyalty: the complex relationship between image, service quality and satisfaction. International Journal of Bank Marketing, 16(7), 276-286.

Bülbül, H., Akın, M., Demirer, Ö. ve Doğan, İ. C. (2012). Türk Bankacılık Sektöründe Hizmet Kalitesinin Müş̧eri Tatmini ve Tekrar Satın Alma Niyeti Üzerine Etkisi: Yapısal Eşitlik Modeli İle Bir İnceleme. Doğuş Üniversitesi Dergisi, 13(1), 28-40.

Çelik, M. K. (2010). Bankaların Finansal Başarısızlıklarının Geleneksel ve Yeni Yöntemlerle Öngörüsü. Celal Bayar Üniversitesi İ.I.B.F. Yönetim ve Ekonomi Dergisi, 17(2), 129-143.

Çiçek, R. ve Doğan, İ. C. (2009). Müşteri Memnuniyetinin Artırılmasında Hizmet Kalitesinin Ölçülmesine Yönelik Bir Araştırma: Niğde İli Örneği. Afyon Kocatepe Üniversitesi İ.I.B.F. Dergisi, 11(1), 199-217.

Çolak, Ö. F. (2012). Türk Bankacılık Sektörünün Şubat 2001 Krizi Sonrası Durumu ve Yeniden Yapılandırma Programı. Ankara: Discussion Paper, No. 2012/14, Turkish.

Demirel, E., Atakişi, A. ve Abacıoğlu, S. (2013). Bankacilık Faaliyet Oranlarının Panel Veri Analizi: Türkiye'deki Kamu, Özel Ve Yabancı Sermayeli Bankaların Durumu. Muhasebe ve Finansman Dergisi, 15(59), 101-112.

Demirel, Y. (2007). Türk Bankacılık Sektöründe Müşteri İlişkileri Yönetiminin Müşteri Sadakati Üzerine Etkisi. Kocaeli Üniversitesi Sosyal Bilimler Enstitüsü Dergisi, 13(1), 56-81.

Doğan, M. (2013). Katılım ve Geleneksel Bankaların Finansal Performanslarının Karşılaştırılması: Türkiye Örneği. Muhasebe ve Finansman Dergisi, 15(58), 175-188.

Emir, M. ve Atukalp, E. (2018). Türk Bankacılık Sisteminde Mevduat Bankalarının Aktif Kalitesi ve Kârlılık Analizi. Atatürk Üniversitesi İktisadi ve İdari Bilimler Dergisi, 32(3), 577-600.

Erdoğan, B.Z., Develioğlu, K., Gönüllüoğlu, S. ve Özkaya, H. (2006). Kurumsal İmajın Şirketin Farklı Paydaşları Tarafından Algılanışı Üzerine Bir Araştırma. Dumlupınar Üniversitesi Sosyal Bilimler Dergisi, 15: 55-76.

Eroğluer, K. (2013). Hizmet Kalitesi Algısının Kurumsal İmaja Etkisi Üzerine Hizmet Sektöründe Bir Araştırma. Anadolu Üniversitesi Sosyal Bilimler Dergisi, 13(4), 29-46.

Gerrard, P. ve Cunningham, B. (2001). Bank service quality: A comparison between a publicly quoted bank and a government bank in Singapore. Journal of Financial Services Marketing, 6(1), 50-66.

Glaveli, N., Petridou, E., Liassides, C. and Spathis, C. (2006). Bank service quality: evidence from five Balkan countries. Managing Service Quality, 16(4), 380-394.

Gülhan, Ü. ve Uzunlar, E. (2011). Bankacılık Sektöründe Kârlllı̆̆ı Etkileyen Faktörler:Türk Bankacılık Sektörüne Yönelik Bir Uygulama. Atatürk Üniversitesi Sosyal Bilimler Enstitüsü Dergisi, 15(1), 341-368.

Işık, O., Akbolat, M. ve Ünğan, M. C. (2013). Kamu Ve Özel Banka Müşterilerinin Hizmet Kalite Algılarının Değerlendirilmesi: Bir Alan Araştırması. İşletme Bilimi Dergisi, 1(2), 51-67.

Kalyoncuoğlu, S. ve Faiz, E. (2016). Hizmet Kalitesinin Kurumsal İmaja Etkisi: Kamu ve Özel Mevduat Bankaları Üzerinde Bir Araştırma. Pazarlama ve Pazarlama Araştırmaları Dergisi, 9(17), 67-103.

Konak, F. ve Kendirli, S. (2014). Küresel Finansal Kriz Sürecinde BİST 100 Endeksi'nde Haftanın Günleri Etkisinin Analizi. Süleyman Demirel Üniversitesi İktisadi ve İdari Bilimler Fakültesi Dergisi, 19(2), 275-286.

Ladhari, R., Ladhari, I. and Morales, M. (2011). Bank service quality: comparing Canadian and Tunisian customer perceptions. International Journal of Bank Marketing, 29(3), 224-246.

Öncü, M. A., Kutukız, D. ve Koçoğlu, M. (2010). Hizmet Kalitesinin Ölçülmesi ve Bankacılık Sektöründe Bir Uygulama. Muhasebe ve Finansman Dergisi, 12(45), 237-252.

Patricio, L., Fisk, R. P. and Cunha, J. F. (2003). Improving satisfaction with bank service offerings: measuring the contribution of each delivery channel. Managing Service Quality, 13(6), 471-482.

Parasuraman, P., Zeithaml, A. and Berry, L. (1985). A Conceptual Model of Service Quality and its Implications for Future Research. Journal of Marketing, 41-50 


\section{F. Day1 - B. Yıldız 12/1 (2020) 1-17}

Sakarya, Ş. (2010). CAMELS Derecelendirme Sistemine Göre İMKB'deki Yerli ve Yabancı Sermayeli Bankaların Karşılaştırmalı Analizi. Akademik Araştırmalar ve Çalışmalar Dergisi, 2, 7-21.

Schermelleh E.K., Moosbrugger, H. and Müller H. (2003). Evaluating the fit of structural equation models: tests of significance and descriptive goodness-of-fit measures. Methods of Psychological Research Online, 8 (2): 23-74.

Shanka, M. S. (2012). Bank Service Quality, Customer Satisfaction and Loyalty in Ethiopian Banking Sector. Journal of Business Administration and Management Sciences Research, 1(1), 1-9.

Şahin, K. (2013). Cinsiyete Göre Bankacıllk Sektöründe Hizmet Kalitesi Üzerine Bir Araştırma. EUL Journal of Social Sciences, IV(I): 34-48.

Taşkın, Ç., Akat, Ö. ve Erol, Z. (2010). Tüketicilerin Banka Tercihini Erkileyen Faktörlerin Belirlenmesi: Bursa'da Bir Araştırma. Anadolu Üniversitesi Sosyal Bilimler Dergisi, 10(3), 11-22.

Taşkın, F. D. (2011). Türkiye'de Ticari Bankaların Performansını Etkileyen Faktörler. Ege Akademik Bakış, 11(2), 289-298.

Türkiye Bankalar Birliği (2019, 20 07). İstatistiki Bilgiler. Türkiye Bankalar Birliği: ttps://www.tbb.org.tr/tr/bankacilik/banka-ve-sektor-bilgileri/istatistiki-raporlar/59 adresinden alınmıştır. Toktaş, P. ve Gül, B. (2016). Bir Bankanın Hizmet Kalitesinin Ölçülmesi. Bankacılık ve Sigortacılık Araştırmaları Dergisi, 2(9), 8-27.

Usta, R. ve Memiş, S. (2009). Hizmet Kalitesi ve Marka Bağlllığı Arasındaki İlişki Üzerine Müşteri Tatmininin Aracılık Etkisi. Atatürk Üniversitesi İktisadi ve İdari Bilimler Dergisi, 23(4), 87-108.

Ustasüleyman, T. (2009). Bankacılık Sektöründe Hizmet Kalitesinin Değerlendirilmesi: Ahs-Topsis Yöntemi. Bankacilar Dergisi(69), 33-43.

Yılmaz, V., Çelik, H. ve Depren, B. (2007). Devlet ve Özel Sektör Bankalardaki Hizmet Kalitesinin Karşılaştırılması: Eskişehir Örneği. Doğuş Üniversitesi Dergisi, 8(2), 234-248.

Yücel, M. (2013). Toplam Hizmet Kalitesinin Servqual Analizi İle Ölçümü: Bankacılık Sektöründe Bir Araştırma. Elektronik Sosyal Bilimler Dergisi, 12(44), 82-106. 